\title{
Economic Analysis of the Investment in Smart Substation
}

\author{
Yaping Wang \\ State Grid Beijing Economic and Technology Research Institute, Beijing, China \\ Email: wangyaping@chinasperi.sgcc.com.cn
}

Received 2013

\begin{abstract}
Intelligent Substation as one of the core components converting and managing energy within sturdy and smart power grid system coordinates electricity generation, transformation, transmission, distribution, usage and dispatching. In this paper, a thorough contrast was made between intelligent and conventional substation in terms of technical deployment, investment scale etc. Using life-span cycle technique, the economic analysis of intelligent substation revealed some key factors that dictate economy level. Finally, some rational proposals for decision makes to promote smart grid were given to improve economy of intelligent substation with a reasonable construction scale and sequence.
\end{abstract}

Keywords: Intelligent Technology; Whole Life Cycle; Investment Economy

\section{Introduction}

Smart grid is China's future needs to achieve a lowcarbon and sustainable development. The intelligent substation convergence of smart grid power generation, transmission, substation, distribution, electricity and scheduleing six links, one of the core platforms is strong and smart grid construction, energy conversion and control, but also wind, solar and other new important support energy connected to the grid [1].

China has put into operation more than 100 intelligent substations, to achieve a major breakthrough in the field of intelligent substation core technology research and development, key equipment development and product manufacturing, the breakthrough in the Chinese occupied the international leader in intelligent substation technology to become the world leader of intelligent substation technology. According to the life cycle cost analysis, analysis of intelligent substation investment economic analysis of the key factors affect the economy of intelligent substation investment scale of intelligent substation construction and construction timing, to promote the development of the smart grid to provide decision-making reference for the rational distribution.

\section{The Smart Substation with Conventional Substation Technical and Economic Differences}

The intelligent substation characterized equipment maintenance operation the substation do it all digital information transmission network, the communication model of standardization, so that a variety of devices and functions to share unified information platform, a break- through in the traditional sense as to the artificial guardianship and operation the main mode, the computer "one-click" process operation. Compared with conventional substation intelligent substation to better meet the technical and functional smart grid information technology, automation, interactive requirements, it is put into operation, can significantly improve the equipment intelligent level and the equipment running reliability, achieve the unattended and equipment operation automation to improve the efficiency of resource use and production management, running more economical, energy-saving and environmental protection [2].

Due to the increase of intelligent devices, the smart substation initial investment than conventional substation certain level of increase, according to 7 smart substation project statistics, with the same size and the same level of the building conventional substation compared to the smart substation initial investment increased by $2.9 \%$ to $5.1 \%$.

Substation intelligent, reduce operating costs, reduce equipment failure caused the outage cost, Statistics based on the intelligent substation engineering data has built, with the same size and the same level of the building substation, compared the intelligent substation late running costs can be reduced by $21 \%$ to $32 \%$.

\section{Reason Intelligent Substation with Conventional Substation Investment Differences}

Compared with the conventional substation of the same size and the same level of the building, the the intelligent substation initial investment will increase from 
$2.9 \%$ to $5.1 \%$. Four in the initial investment costs (buildings, equipment, installation, and others), intelligent and not all costs increase, compared with the conventional substation, major equipment purchase costs, construction costs, installation the engineering fees decreased substantially, has built in smart substation project statistics, equipment purchase costs than conventional stations increased by $3.3 \%$ to $5.9 \%$,construction costs decreased by $3.2 \%$ to $6.2 \%$ than the conventional station, installation costs than conventional stations decreased by $2.3 \%$ to $5.8 \%$.

Smart substation equipment purchase costs compared to the conventional station high reason to increase the intelligent device. The smart substation with traditional substation biggest difference is reflected in the following three aspects: a device intelligent the secondary device networking, device status visualization. It is these three areas of difference so smart substation intelligent terminal than conventional stations, merged cells, electronic transformer, increase equipment online monitoring device, process layer network switches and related integration platform, application software, such as a direct result of the the increase of the costs of purchasing equipment, as follows:

(1) Equipment intelligent. The intelligent substation than conventional station intelligent terminal device electronic transformer, merged cells, cancel the main transformer body, and in the pressure side of the bushing current transformers. Rogowski coil and pure optical fiber electronic transformer ratio is basically half and half, most of the electronic voltage transformer capacitance division type the partial AIS substation electronic transformer installed in combination with a circuit breaker or disconnecting switch Alpha.

(2) Secondary device networking. Substation secondary equipment unified networking star network structure. Substation automation systems, compared with conventional substation to increase the process layer switch 220 $\mathrm{kV}$ and above all independent protection, measurement and control devices, IEC 61588 when the way has not yet been widely adopted in the level of $220 \mathrm{kV}$ and above high-voltage substation spacer layer, process layer The device is still the way to when using IRIG-B. To some extent, intelligent auxiliary control system video, security, environmental monitoring subsystem interoperability and linkage to improve substation automation.

(3) The status of the device visualization-Intelligent Substation Configuration online monitoring system, independent condition monitoring station configuration back-office systems, condition monitoring IED configuration monitoring content. Advanced application functionality integration backstage unified consideration by the monitoring system, implemented in phases. At this stage most of the sequence control and comprehensive analysis of the policy-making functions of the smart alarm and fault information. Prepared from the cast function integration platform by the station within the small current line selection function, part of substation protection and fault information management sub-station, the low-frequency voltage load shedding function is realized by the integration platform within the station, AC, DC, communications station The power integrated design.

Smart substation construction cost than a conventional station, a decrease of $3.2 \%$ to $6.2 \%$, mainly because of the intelligent substation will measure, control, monitoring and protection functions fully integrated secondary equipment cubicle $50 \%-70 \%$ less than conventional station, the second The equipment room area of a corresponding reduction in $60-100 \mathrm{~m}^{2}$, With the substation communications platform network, control cable usage compared with conventional stations decreased by $60-80 \%$ and 50\%-70\%, thereby reducing the cable trench.

Intelligent Substation installation costs compared to the conventional station a decrease of $2.3 \%$ to $5.8 \%$, mainly because intelligent substation secondary equipment cubicle than conventional station reduced by $50 \%$ $70 \%$, a corresponding reduction in installation costs, along with substation communication network platformtimes the cable length is reduced by $60 \%$ - $80 \%$ on average, and a corresponding reduction in installation costs

\section{Intelligent Substation Life Cycle Cost Analysis}

The life cycle cost (LCC) analysis is a departure from the equipment project's long-term economic benefits, and take full account of the equipment, project planning, design, manufacture, purchase, installation, operation, maintenance, renovation, updating until scrapped process, so that the life cycle cost of a management concepts and methods to minimize. This method is scientifically divided all the costs of the equipment in the life cycle, and the use of statistical data and establish cost estimates of the relationship and the cost model, which may be different from the needs of a fairly accurate estimate of the life cycle cost of the equipment or items for decisionmaking and management of need. Its core content of the total life cycle cost of the equipment, project or system analysis and decision-making [3].

Smart substation to $110 \mathrm{kV}$ Beichuan life cycle cost analysis, the scale of construction: $110 \mathrm{kV}$ main transformer Current 2, the final two sets, volume $2 \times 50$ MVA; $110 \mathrm{kV}$ cable entry Current back the final two back outdoor GIS combination appliances within the bridge wiring; $10 \mathrm{kV}$ Current qualify 18 back, final qualifying 24 back, single busbar wiring; $10 \mathrm{kV}$ capacitor Current 4 groups, the final four groups.

The intelligent substation life cycle cost (LCC) is the total fees paid in the smart the substation economic life cycle consists of the following parts: the cost of power 
outages caused by the loss of the initial investment costs (IC), operating costs (OC), equipment failure(FC), destruction of equipment costs (DC) [4]. Therefore the intelligent substation life cycle cost (LCC) is calculated as follows:

\section{$\mathrm{LCC}=\mathrm{IC}+\mathrm{OC}+\mathrm{FC}+\mathrm{DC}$}

According to the $110 \mathrm{kV}$ Beichuan smart substation infrastructure data and run the repair data, as well as conventional $110 \mathrm{kV}$ substation infrastructure and run maintenance data, can be calculated as follows:

The Intelligent Substation $110 \mathrm{kV}$ Beichuan IC is 29280000 yuan, if the conventional station construction, the IC is 27500000 yuan.

The $110 \mathrm{kV}$ Beichuan smart substation OC 231000 yuan/year, conventional station construction, OC 425000 yuan/year. Intelligent substation devices "routine maintenance" changes to the state maintenance, extend equipment maintenance cycle, reduce inspection costs 12000 yuan/year, reduce repair cost 11000 yuan/year; the substation remote operation, protection the soft platen remote control switching means to reduce operating costs 96000 yuan/year; high luminous efficiency light source through LED lights and solar high-efficiency energysaving green lighting, electricity savings of 75000 yuan / year.

The $110 \mathrm{kV}$ Beichuan smart substation FC is 0 yuan / year, conventional station construction, FC is 210000 yuan/year. Mainly because intelligent substation equipment online monitoring, can advance to find fault and timely processing, basic does not appear to cause power outages due to equipment failure, thus greatly reducing the cost of the outage cost.

The $110 \mathrm{kV}$ Beichuan smart substation DC is 50000 yuan, and the conventional station construction, DC is 150000 yuan. The smart substation scrapped equipment can produce residual value higher income, retirement costs are lower than conventional substation.

Assumptions intelligent equipment life of 15 years, the 2012 price for the base price, long-term loan interest rate of 6.55 percent as the discount rate, ,According to the formula: $\mathrm{LCC}=\mathrm{IC}+\mathrm{OC} \times(\mathrm{P} / \mathrm{A}, 6.55 \%, 15)+\mathrm{FC} \times$ $(\mathrm{P} / \mathrm{A}, 6.55 \%, 15)+\mathrm{DC} \times(\mathrm{P} / \mathrm{F}, 6.55 \%, 15)$, can be calculated the following results:

LCC(Intelligent Substation $)=31400000$ yuan

LCC (Conventional Substation $)=33340000$ yuan

LCC(Intelligent Substation) $<$ LCC Conventional Substation), The intelligent substation investment economy better than conventional substations, low prices will increasingly intelligent devices and With intelligent technology matures, the increased investment will be reduced year by year, the cost savings will increase year by year, intelligent substation the economy will be very competitive

\section{The Intelligent Substation Investment Economic Impact Factors}

LCC suggests that, whether it is smart the substation or conventional substation, the proportion accounted for by the initial investment (IC) in the LCC are in one, but also a considerable proportion, so we can determine the impact of the LCC main factor is the IC, so want to reduce the intelligent Substation LCC, improve its investment economy, we have the following recommendations:

(1) Large-scale production of smart devices and centralized bidding

With the smart device manufacturing technology, manufacturing processes continue to mature and widely used smart devices will achieve mass production, the smart device production from the investment period the mature stage, the early equipment costs will be quickly sharing equipment unit price will drop substantially. For example, 2009-2012 equipment with the $220 \mathrm{kV}$ gas density and micro-water line monitoring device, because the device has entered a mature stage from the investment period, the equipment prices fell by $76.7 \%$.

With the further expansion of the smart device market, the smart procurement of equipment have been included in the State Grid Corporation of centralized bidding system, due to the large-scale procurement, the equipment supplier gives the best price, which makes electronic current and voltage transformers, electronic are more substantial decline in equipment prices from the previous month of the current transformers, electronic voltage transformers, main transformer line monitoring device, circuit breaker line monitoring devices.

With the sharp decline of the substation intelligent equipment purchase costs, the intelligent substation initial investment also dropped, LCC (smart Station) will become smaller and smaller, the intelligent substation investment economy will become more and more obvious.

(2) Optimized design, the promotion of universal design of intelligent substation

As the the Intelligent Substation key technology matures and the core equipment of the application, design, optimization, and intelligent substation universal design popularization and application of future intelligent substation investment is expected to have a more significant decline than the current.

With the measurement of substation, control, monitoring, protection, and other functions fully integrated, will gradually reduce the number of substation secondary equipment, the secondary device screen cabinet is expected to be reduced by $50 \%$ to $70 \%$, a corresponding reduction in the secondary equipment room area of 60 $100 \mathrm{~m}^{2}$. With the continuous development and promotion of the use of network communication technology and IEC 61588 when technology such as substation commu- 
nication network platform, secondary cable length is reduced by an average of $8-40 \mathrm{~km}$, the cable channel is reduced by $80 \%$ to $90 \%$.

As the smart substation technology matures, the promotion of universal design of intelligent substation, not only to reduce the difficulty of design, and the construction and commissioning work will also be difficult to significantly reduce the engineering investment will have a certain level of decline.

\section{Conclusions}

Intelligent Substation compared with conventional substation, device status visualization, smart alarm the smart against misuse intelligent advanced applications, reducing the maintenance time of power outages and the failure of electricity [5], the main use of the equipment cycle has been extended, while area there is a certain decrease in technology have obvious advantages. With the advances in smart substation technologies in the future, large-scale production of the smart device applications and smart devices centralized procurement brings economies of scale, the smart substation investment will con- tinue to decline, investment in smart substation and conventional the substations investment basic flat or even lower than the conventional substations investment with better prospects for the economy and promote.

\section{REFERENCES}

[1] J. H. Bai, "Strong and Smart Grid Development Mode and Its Effectiveness Studies,” Energy technologies and Economic, Vol. 22, No. 10, 2010, pp. 1-6.

[2] Y. B. Liu, "Mechanism of the Development of Smart Grid and Grid Automation Technology,” Energy Technologies and Economic, Vol. 22, No. 11, 2010, pp. 25-30.

[3] Z. D. Wang, J. Li and P. Zhang, "Smart Grid Evaluation Index System,” Energy Technologies and Economic, Vol. 22, No. 8, 2010, pp. 23-26.

[4] H. B. Zhang, J. R. Li and W. H. Yang, "Smart Grid Pilot Project Evaluation Index System Research," Energy Technologies and Eeconomic, Vol. 22, No.12, 2010,pp. 11-15.

[5] M. Zeng, "Cost-benefit Analysis of the Field Profile Intelligent electricity measures,” Energy Technologies and Economic, Vol. 23, No. 1, 2011, pp. 21-24. 